\title{
CREATIVITY AND ART: A POEM THAT TEACHES ABOUT SOLID HEALTH WASTE DISPOSAL
}

\author{
Edna Maria da Cruz, Daniela Aparecida Rosendo de Souza, Daniela de Fátima Diniz, \\ Fernanda Macedo Roldão, Geisa Sacramento Baú, Micaela de Araújo Saraiva, Olivia Beloto \\ da Silva* \\ *E-mail: libeloto@yahoo.com.br \\ Universidade Paulista, Barueri, Brasil \\ DOI: $10.15628 /$ rbept.2020.7869
}

Artigo submetido em out/2018 e aceito em out/2019

\begin{abstract}
The inclusion of courses in environmental education in the curriculum of health sciences is still limited in Brazil. Then, the objective of the present study was to develop a Creative Presentation for the Solid Health Waste Disposal theme, in order to contemplate an Educational Approach in Health as a prerequisite for the Work Safety discipline, in the Technical Nursing Course. The students created a Poem that describes how solid health waste is classified, how and where each type of waste should be separated and if the waste causes any damage to the environment and/or public health. As a result, the students were stimulated with active methodologies that favor learning and allow the teaching and learning processes to surpass the walls of the school, especially when this exercise is performed by nursing students, who will be future health educators.
\end{abstract}

Keywords: Solid Health Waste. Nursing. Creativity.

\section{CRIATIVIDADE E ARTE: UM POEMA QUE ENSINA SOBRE O DESCARTE DE RESÍDUOS SÓLIDOS DE SAÚDE}

\section{RESUMO}

A inclusão de cursos de educação ambiental no currículo das ciências da saúde ainda é limitada no Brasil. Assim, o objetivo do presente estudo foi desenvolver uma apresentação criativa para o tema Descarte de Resíduos Sólidos em Saúde, favorecendo uma abordagem educacional em saúde, como pré-requisito para a disciplina Segurança do Trabalho, do Curso Técnico de Enfermagem. Os alunos criaram um poema que descreve como os resíduos sólidos de saúde são classificados, como e onde cada tipo de resíduos deve ser separado e se os resíduos causam danos ao meio ambiente e / ou à saúde pública. Como resultado, os alunos foram estimulados utilizando metodologias ativas que favorecem a aprendizado e permitem que os processos de ensino-aprendizagem ultrapassem os muros da escola, principalmente quando esse é realizado por estudantes de enfermagem, que serão futuros educadores em saúde.

Palavras-Chave: Resíduos Sólidos de Saúde. Enfermagem. Criatividade. 


\section{INTRODUCTION}

The quality of life of an individual is based on several suitable conditions, such as air with low pollution, water for drinking and personal hygiene; a city that is beautiful, clean and green, with sanitation, security and resources for leisure, among others (BRANCO and ROCHA, 1984; PÁDUA, 2002). In order to understand the true meaning of "pollution", the concept of the Environment, which was established by the National Environmental Policy (Law 6.938/81), should be taken into account as the set of conditions, laws, as well as influences and interactions of physical, chemical and biological processes that permit, harbor and govern all forms of life (SANTOS, 2004). If the concept of the environment pertains to the idea of elements and factors being in equilibrium, then pollution will exist whenever wastes (i.e. solids, liquids or gases), produced by microorganisms or man-made, are in excess to the absorption capacity of the environment, thus causing changes to the existing physical conditions and affecting the survival of the species (SANTOS, 2004).

Among the most important environmental problems that will affect the environment and human health for the next hundred years are: climate change, water scarcity, desertification, water pollution, loss of biodiversity, waste disposal, depletion of natural resources, natural disasters, rising sea levels, among others (SANTOS, 2004).

The environment has an intricate relationship with the health of the population. The place where people live, work and study interacts with the individual and considerably impacts the health-disease process. With regard to environmental and occupational risks to humans, about $24 \%$ of diseases and $23 \%$ of deaths occur due to modifiable environmental factors, such as: outdoor air pollution; indoor pollution by burning of solid fuel; exposure to lead; water; sanitation and hygiene, climate change and occupational factors (MINISTÉRIO DA SAÚDE, 2002). Considering these aspects, from the beginning of this century, the preservation of the environment was no longer treated as a matter by a small group of people, who warned of the need to preserve the greatest good of life, and began to be observed with more attention by different groups (SANTOS, 2004; BRANCO and ROCHA, 1984). Thus, to consider the environment as a source of energy necessary for the maintenance of all life forms is to recognize that we all depend on this source of energy for survival, including humans, who are responsible for its degradation (SANTOS, 2004).

Environmental Education emerged in the 1960 s as a strategy for preserving the environment. In the following decade, international discussions were already being held on environmental issues. In 1977, the 1st Intergovernmental Conference was held to define the principles, objectives and characteristics of Environmental Education. In it, a criticism of reality was made, demonstrating that the main reason for the current degradation of the 
environment has its origin in the capitalist system, in which the human being does not identify himself as part of nature, but rather as one that dominates it (LAYARGUES, 2000). Finally, regarding the importance of education, Law No. 9.795/99, which establishes the National Environmental Education Policy, states that "environmental education is an essential and permanent component of national education, and must be present, in an articulated way, at all levels and modes of the educational process, both formal and nonformal".

Historically, health education aims to establish a link between the population and health, collaborating to construct an idea of treatment as well as cures, observed in the present day. In nursing, health education is important since it can determine how individuals and their families are able to learn behaviors that encourage them to care of themselves and the environment (FIGUEIREDO, 2005). It is worth emphasizing that Health Education can be carried out by several sectors of society, including the participants of social movements, professionals and popular health agents. Thus, the construction of knowledge and changes in the concepts of the health-disease process are part of the reflection of the health practices performed by referral services, who collaborate to formulate several alternatives to the problems encountered by the community. All of these processes strengthen the promotion of health, since it allows the community to participate by providing information, health education and improvements in healthier habits and attitudes, which is a fact that helps to improve the quality of community life, culminated by consequent individual improvements (FIGUEIREDO, 2005).

Nursing has great importance in health education when it comes to the health-disease process and its relationship with the environment. Health professionals and nursing students are able to adequately conceptualize the environment and health, as well as all the variables that act on them, but fail to transfer this knowledge into professional practice. However, they do understand the importance of discussing this topic during training courses, making this a positive point in this discussion (BRUZOS, et al., 2011).

The International Code of Nursing assigns a responsibility to the nursing professional for the preservation of the environment, towards the goal of avoiding its degradation (CAMPONOGARA et al. 2006; CÓDIGO INTERNACIONAL DE ENFERMERIA, 2000). Although this task is legally attributed, it is still difficult for these professionals to associate this topic with their training. The example of the International Code is very interesting, since assigning legal responsibility to professionals (in general) with the environment is the first step towards a major change, which begins in the classroom, discussing questions about the environment and health in a deeper way, and in the context of the pathologies associated with the lack of adequate basic sanitation (BRUZOS, et al., 2011; RIBEIRO and BERTOLOZZI, 1999).

Additionally, several factors make it difficult to learn about the environment and health, such as: low scientific production, lack of financial 
resources, disinformation of the population and resistance to the division of responsibilities. With regards to low scientific production, it is observed that countries like the United States, Russia and Ukraine concentrate a great part of their publications to addressing environmental questions. Since 2000, in Brazil, there has been a significant increase in environmental publications, which indicates an increase in the number of research centers and research groups that focus on the environment. Despite this increase, there is still a lack of expressive publications correlated to health and environmental issues, since these themes are mostly published in isolation (CAMPONARA et al., 2008).

All of these observations demonstrate the importance of combining theoretical, practical, methodical and interventionist knowledge to create an adequate concept about the subject, avoiding some of the most common actions in the health sector, which are mostly concerned with solving problems. Thus, what is important is that the primary actions for the promotion and prevention of risks, both to the environment and to humanity, are taken before the deleterious effects on them can arise. An example of this is the broader discussion on the basic health issue through an approach that promotes health and the conservation of the environment as a whole (CAMPONARA et al., 2008).

The inclusion of environmental education in the curriculum of health courses has been limited, which makes it very difficult when discussing this topic in the classroom. It is worth stressing the importance of this discussion, since the environmental problems such as improper waste disposal, burnings, lack of sanitation, among others in the areas where students live, work and/or study, are directly linked to the emergence of diseases that can cause respiratory complications, diarrhea, and attraction of carriers that cause countless diseases. Thus, courses that have the discipline or approach the theme of Environmental Health become innovative, since Brazil still has to adjust its economic growth in an environmentally sustainable way. This will require a large number of environmental and health professionals capable of adopting strategies to achieve sustainability (MINISTÉRIO DA SAÚDE, 2002; FREITAS, 2003).

With this in mind, the present study presents an experience report, which demonstrates a creative way of presenting a group work on Solid Health Waste, carried out in the classroom by the students of the third module, in the Technical Nursing Course, at the Technical Institute of Barueri Engenho Novo, which is a school that belongs to the Fundação Instituto de Educação de Barueri.

\section{OBJECTIVE}


Prepare a Creative Presentation on Solid Health Waste, in a way that contemplates an Educational Approach in Health, as a prerequisite for the discipline of Work Safety.

\section{METHOD}

The students were distributed a research topic and given 4 months to complete the work. The students were required to discuss the best way to present the work, create a presentation and, finally, present the project to their classmates.

\section{RESULTS}

In order for them to contemplate the criteria for the preparation of the work, they decided to create a Poem about the different types of Solid Health Wastes that could be generated in a health institution. The poem has rhymes and well-placed phrases, which show the classification of these wastes, how and where they should be separated and whether they pose any harm to the environment and/or human health (Annex 1).

\section{FINAL CONSIDERATIONS}

Stimulating students with active methodologies promotes learning and stimulates creativity. In addition, when these methodologies are associated with the disciplines that favor discussions about the Environment and Sustainability, it allows the teaching and learning processes to surpass the walls of the school. These actions, when carried out by nursing students, who will be future health educators, are extremely valuable for the construction of a more sustainable world and the formation of more socially engaged individuals.

\section{REFERENCES}

BRANCO SM; ROCHA AA. Ecologia: Educação Ambiental: Cências do Ambiente para Universitários. s.I. : COMPANHIA DE TECNOLOGIA DE SANEAMENTO AMBIENTAL - CETESB, 1984.

BRASIL. MINISTÉRIO DA SAÚDE. SECRETARIA DE POLÍTICAS DE SAÚDE. Projeto Promoção da Saúde. As Cartas da Promoção da Saúde / 
Ministério da Saúde, Secretaria de Políticas de Saúde, Projeto Promoção da Saúde. - Brasília: Ministério da Saúde, 2002.

BRUZOS GAS, ET AL. Meio Ambiente e Enfermagem: suas interfaces e inserção no ensino de graduação. Saúde So. . 2, Vol. 20, p. 462 - 469, 2011.

CAMPONOGARA S; KIRCHHOF, ALC; RAMOS, FRS. A relação enfermagem e ecologia: abordagens e perspectivas. Revista de Enfermagem, Rio deJaneiro, v. 14, n. 3, p. 398-404, 2006.

CAMPONOGARA S; KIRCHHOF, ALC; RAMOS, FRS. Uma revisão sistemática sbre a produção científica em ênfase na relação entre saúde e meio ambiente. Ciênc. Saúde Coletiva. 2, Vol. 13, p. 427 - 439, 2008.

CÓDIGO INTERNACIONAL DE ENFERMERIA, Genebra (Sw): Consejo General de Enfermeria, 2000.

FIGUEIREDO NMA. Ensinandoa Cuidar em Saúde Pública. São Caetano: s.n., 2005.

FREITAS CM. Problemas ambientais, saúde coletiva e ciências sociais. Ciências e Saúde Coletiva. Vol. 8, p. 137 - 150, 2003.

LAYARGUES PP. Sistemas de Gerenciamentos Ambiental Tecnologico, Limpa e Consumidor Verde: Revista de Administração de Empresa - Meio Ambiente No Ecocapitalismo.,São Paulo, v. 40, oㅡ, p. 80- 88, 2000.

PÁDUA JA. Dois séculos de crítica ambiental no Brasil. [A. do livro] M. C. S Minayo e A. Miranda. Saúde e Ambiente Sustentável: estreitando nós. Rio de Janeiro : Fiocruz, 2002.

RIBEIRO MCS; BERTOLOZZI MRA. A enfermagem e questão ambiental proposta de um modelo teórico para o exercício profissional. Rev. Bras. Enferm. Vol. 52, p. 365 - 374., 1999.

SANTOS FP. Meio Ambiente e Poluição. 2004. Disponível em: https://jus.com.br/artigos/4753/meio-ambiente-e-poluicao . Acesso em: $08 / 11 / 2017$. 


\section{Annex 1.}

Do you know what solid health waste is?

Pay attention and let us explain this

These are the materials that the hospital will generate

So we have to be careful of where we discard and how we separate

The National Environmental Council makes the distinction

There are groups that each type of solid health waste fits in

We have groups and colors to differentiate

Be careful! This pertains to health, we cannot go wrong, and must not deviate!

What about the white bag? What can go in it?

Anatomical parts, gauzes and probes are permitted

Laboratory plates and slides can also be placed

These are biological risks that make up group A waste

Be very careful not to get contaminated

In the end it will all be incinerated.

Flammable, corrosive, reactive and toxic we want to alert you

For example, antineoplastics, immunosuppressants and reagents too

These are the chemical risks, within group $\mathbf{B}$, which can cause harm

It contains risks to public health and the environment that cause alarm

These types of waste must be returned to the original container

Then placed inside an unbreakable vessel to increase safety and reduce danger

Group C waste shall be placed in a shielded receptacle

Because they are radioactive and very serious health damage will be detectable

These are nuclear medicine and radiotherapy materials that we need to pay attention to

If we are careless great evil can ensue

With group D we do not have any fear

It includes home waste and all in the black bag we can put here

This is waste that does not have biological, chemical or radiological risks

Food leftovers, administrative waste are some examples this group consists

And thinking about the environment some of this waste can be recycled

This is a simple practice that we can adopt and is unrivalled

And group E we cannot blunder about

This is the group that contains sharps that we're going to throw out.

Needles, glass ampoules, scalpel blades can injure and contaminate

Not forgetting 2/3 of its capacity, so do not overestimate

Group $E$ must also be incinerated 
ISSN - 2447-1801

Pay attention, help the next, and our health will be celebrated!!! 